\title{
EVALUASI BAHASA ARAB DALAM RANAH KEMAMPUAN KOGNITIF PESERTA DIDIK
}

\author{
Dony Ahmad Ramadhani \\ Dosen Tetap Prodi Pendidikan Bahasa Arab STIQ Amuntai \\ Ahmadramadhani77@gmail.com
}

\begin{abstract}
Abstrak
Urgensi evaluasi di masa sekarang bukanlah hal yang patut dianggap sepele, karena akan ber-implikasi kepada hasil dari sebuah proses pembelajaran, banyak yang berkeyakinan jika strategi guru sudah baik dan tepat maka pembelajaran akan berhasil, sehingga terkadang tidak memperhatikan evaluasi serta cenderung hanya menggunakan butir-butir tes yang sudah tersedia di buku tanpa memperhatikan esensi-esensi lain secara eksternal seperti keadaan dan pemahaman peserta didik. Padahal signifakansi dari sebuah strategi dan metode belajar adalah bagaimana peserta didik mencapai hasil belajar sesuai dengan tujuan dari pemerintah dan lembaga di mana peserta didik tersebut mengemban ilmu, dan tidak selamanya peserta didik dapat mencerna keseluruhan pembelajaran dengan perbedaan kemampuan yang ada. Terlebih khusus dalam pembelajaran bahasa, di mana kemampuan bahasa tidak hanya berfokus kepada nilai tetapi juga kepada peningkatan sebuah kualitas pembelajaran berupa praiktik. Salah satu hal yang perlu diperhatikan dalam proses evaluasi adalah evaluasi dalam ranah kognitif. Evaluasi dalam ranah kognitif merupakan evaluasi yang di dalamnya terdapat pertimbangan terhadap pengetahuan dan kemampuan berfikir peserta didik dalam proses sebuah evaluasi, setiap tingkatan akan memiliki kemampuan yang berbeda sehingga perlunya memperhatikan tingkatan kemampuan berfikir peserta didik agar terciptanya pembelajaran yang berkualitas

Keywords: Evaluasi, Bahasa Arab, Kognitif
\end{abstract}

\section{A. Pendahuluan}

Dalam arti luas, Evaluasi adalah suatu proses merencanakan, memperoleh dan menyediakan informasi yang sangat diperlukan untuk membuat alternatfi-alternatif keputusan ${ }^{136}$. Dengan alternatif inilah pendidik

${ }^{136}$ M. Ngalim Purwanto, Prinsip-Prinsip dan Teknik Evaluasi Pengajaran (Bandung : PT. Remaja Roosdakarya, 2008), h. 3

Jurnal Ilmiah Al QALAM, Vol. 12, No. 1, Januari-Juni 2018 
Dony Ahmad Ramadhani: Evaluasi Bahasa Arab dalam Ranah Kemampuan Kognitif Peserta Didik

dapat menentukan arah-arah yang seharusnya dilaksanakan selanjutnya dalam proses pembelajaran agar terciptanya proses pendidikan yang diharapkan sesuai dengan apa-apa yang dirumuskan dalam tujuan pembelajaran yang dimaksud. Dengan demikian, pembelajaran akan memperoleh kualitasnya, yang bukan hanya dibarengi dengan kuantitas berupa nilai, angka ataupun huruf yang dianggap tinggi, namun peserta didik juga memahami apa yang diajarkan di dalam kelas.

Namun faktanya sekarang agak terlihat berbeda, evaluasi di masa kini masih dipandang sebelah mata, yang mana hanya dianggap sebuah formalitas dalam penyelenggaraan proses pendidikan yang dilaksanakan, baik itu dari lembaga Formal maupun Informal. Walaupun anggapan demikian tidaklah ada pada semua lembaga pendidikan, namun cukup mempengaruhi kualitas hasil belajar peserta didik di Indonesia. karena anggapan inilah, evaluasi sering terlihat tidak tertata rapi dan terkesan tidak mempunyai fungsi selain pemberian nilai dan peringkat.

Keduanya inilah yang biasanya menjadi patokan siswa mengerti atau tidak terhadap pengetahuan dan ilmu yang diberikan di kelas. Namun jika dilihat secara luas, nilai dan peringkat bukanlah satu-satunya cara untuk menjawab sebuah pertanyaan seputar evaluasi dari sebuah proses pembelajaran, tetapi ada hal-hal lain yang lebih penting dan spesifik untuk dilaksanakan. Hal lain inilah yang akan mempengaruhi proses berjalannya evaluasi dalaam sebuah lembaga pendidikan sehingga pendidikan dalam berjalan sebagaimana mestinya.

Salah satunya adalah Kemampuan Kognitif. Evaluasi tidak akan berjalan sukses apabila tidak sesuai dengan kualitas peserta didik, setiap tingkatan tentunya memiliki perbedaan dan memiliki ciri khas tersendiri. Tingkatan itulah yang nantinya akan disesuaikan dengan evaluasi menurut kemampuannya masing-masing. Bisa dibayangkan ketika evaluasi yang dilaksanakan ternyata tidak bisa menyesuaikan tujuan dari pembelajaran dan sesuai dengan kualitas yang dimiliki peserta didik serta tidak sesuai dengan

Jurnal Ilmiah Al QALAM, Vol. 12, No. 1, Januari-Juni 2018 
Dony Ahmad Ramadhani: Evaluasi Bahasa Arab dalam Ranah Kemampuan Kognitif Peserta Didik

tujuan yang diinginkan ketika awal pertama kali pembelajaran direncanakan, padahal evaluasi itu sendiri sebenarnya dimaksudkan ingin mengetahui sejauhmana siswa dapat berkembang sesuai dengan yang dinginkan ketika pembelajaran ingin dimulai, tentunya evaluasi tidak bisa menjadi tolak ukur keberhasilan siswa dalam memahami pembelajaran dan keberhasilan pendidik dalam memberikan sebuah nilai berupa pemahaman ilmu yang diajarkan.

Oleh karena itu, pelaksanaan evaluasi berdasarkan tingkat kemampuan kognitif siswa sangatlah diharapkan dan dianjurkan demi suksesnya sebuah proses pembelajaran. Karena hal demikian, penulis akan sedikit mengulas seputar pengetahuan evaluasi berdasarkan tingkat kemampuan kognitif peserta didik

\section{B. Aspek Kognitif}

Kognitif itu sendiri dapat diartikan dengan sesuatu yang berhubungan dengan pengetahuan ${ }^{137}$. Yang artinya bahwa kognitif itu tidak akan lepas dari yang namanya akal dan pemikiran dan tentang kecerdasan peserta didik. Dalam proses evaluasi, pengetahuan yang diujikan tidaklah bisa ditentukan secara acak dan tanpa perencanaan serta pendekatan terhadap murid terlebih dahulu, karena akan ber-implikasi terhadap hasil dari tes tersebut yang mana tidak hanya memberikan sebuah pukulan telak berupa jawaban yang susah untuk dimengerti dan dijawab, namun juga akan membuat tujuan dari evaluasi tersebut akan semakin buram serta seakan-akan tidak memiliki fungsi apa pun selain hanya menentukan nilai dan peringkat saja. Oleh karena itu, perhatian terhadap aspek kognitif bukanlah hal yang patut ditinggalkan dalam melakukan sebuah tes demi lancarnya sebuah tujuan dari proses pembelajaran.

Jika dilihat secara utuh, kognitif itu sendiri meliputi beberapa aspek seperti, Kemampuan untuk mengontrol, proses pengembangan pengetahuan,

${ }^{137} \mathrm{KBBI}$

Jurnal Ilmiah Al QALAM, Vol. 12, No. 1, Januari-Juni 2018 
Dony Ahmad Ramadhani: Evaluasi Bahasa Arab dalam Ranah Kemampuan Kognitif Peserta Didik

karakteristik individu dalam sebuah pemahaman pengetahuan dan pemikiran kritis.

\section{Perkembangan Kognitif Peserta Didik}

Perkembangan kognitif merupakan salah satu aspek penting dalam proses pembelajaran peserta didik. Perkembangan seorang peserta didik tentunya akan berkembang secara bertahap, sehingga evaluasi yang dilakukan pun seharusnya sesuai dengan tahap-tahap yang berkesesuaian dengan tingkat kognitif anak.

Dari segi perkembangan kognitif, yang diperhatikan bukan hanya keadaan peserta didik secara psikis namun juga dari segi bahasa. Karena bisa jadi peserta didik yang mengikuti evaluasi butir-butir soal berada pada tingkat remaja, namun secara pengetahuan, bahasa yang dipelajari ternyata peserta didik masih berada di tingkat pemula, sehingga butir-butir soal yang dibuat harus sesuai dengan keadaan peserta didik, baik dari sisi pkilogis maupun dari sisi bahasa.

Oleh karena itu, penulis membagi perkembangan kognnitif menjadi dua bagian. yaitu perkembangan kognitif dari sisi Psikologi perkembangan peserta didik dan perkembangan dari sisi bahasa.

\section{Perkembangan kognitif dari segi psikologi}

Tahap-tahap perkembangan intelektual individu serta perubahan umur sangat mempengaruhi kemampuan individu mengamati ilmu pengetahuan. ${ }^{138}$ Mengacu pada teori Piaget, pemikiran anak-anak usia sekolah dasar masuk dalam tahap pemikiran konkret-operasional (concrete operational thougt), yaitu masa di mana aktivitas mental anak terfokus kepada objek-objek nyata atau pada berbagai berbagai kejadian yang pernah dialaminya, dan operasi konkret adalaah aktivitas mental yang difokuskan pada objek-objek yang dapat diukur.

138 Fatimah Ibda, Perkembangan Kognitif: Teori Jean Piaget (Jurnal Intelektualita-Vol. 3.No. 1, Januari-Juni 2015), h. 29

Jurnal Ilmiah Al QALAM, Vol. 12, No. 1, Januari-Juni 2018 
Dony Ahmad Ramadhani: Evaluasi Bahasa Arab dalam Ranah Kemampuan Kognitif Peserta Didik

Ini berarti bahwa anak usia sekolah dasar sudah memiliki kemampuan untuk berfikir melalui urutan sebab-akibat dan mulai mengenali banyaknya cara yang bisa ditempuh dalam permasalahan yang dihadapinya. ${ }^{139}$

Pada tahap ini, anak sudah cukup matang untuk menggunakan pemikiran logika atau operasi, tetapi hanya untuk objek fisik yang ada saat ini, dalam tahap ini, egois anak cenderung berkurang dan kemampuannya dalam tugas-tugas konservasi menjadi lebih baik. Namun, tanpa objek fisik dihadapan mereka, anak-anak pada tahap operasional konkrit masih mengalami kesulitan dalam menyelesaikan tugas logika. ${ }^{140}$

Dalam upaya memahami alam sekitarnya, mereka tidak lagi hanya mengandalkan informasi yang bersumber dari pancaindra, karena ia mulai mempunyai kemampuan untuk membedakan apa yang tampak oleh mata dengan kenyataan sesungguhnya dan antara yang bersifat sementara dan tetap. Pemahaman tentang waktu dan ruang anak sekolah dasar juga semakin baik . Pada masa ini anak telah mengembangkan tiga macam proses yang disebut dengan operasi-operasi, yaitu: negasi, resiprokasi dan identitas ${ }^{141}$

1. Negasi; anak hanya melihat keadaan permulaan dan akhir deretan benda, yaitu pada mulanya keadaannya sama menjadi tidak sama. Anak tidak melihat apa yaang tejadi antara keduanya

2. Hubungan timbal balik (Resuprokasi); Ketika anak melihat bagaimana deretan dari benda-benda it diubah,anak mengetahui bahwa deretan benda-benda bertambah panjang dan tidak rapaat lagi dibandingkan dengan deretan yang lain. Karena anak mengetahui hubungan timbal balik antara panjang dengan kurang rapat

3. Identitas; Anak pada masa konkret sudah dapat mengenal satu per satu benda-benda yang ada pada deretan-deretan itu. Hanya saja, yang

${ }^{139}$ Desmita, Psikologi perkembangan anak (Bandung: PT Remaja Rosdakarya, 2012), Cet ke 4, h. 104

140 Fatimah Ibda, Perkembangan Kognitif: Teori Jean Piaget (Jurnal Intelektualita-Vol. 3.No. 1, Januari-Juni 2015), h. 34

${ }^{141}$ Desmita, Psikologi perkembangan anak,... h. 105

Jurnal Ilmiah Al QALAM, Vol. 12, No. 1, Januari-Juni 2018 
Dony Ahmad Ramadhani: Evaluasi Bahasa Arab dalam Ranah Kemampuan Kognitif Peserta Didik

dipikirkan oleh anak masih terbatas pada hal-hal yang ada hubungannya dengan sesuatu yang konkret, suatu realitas secara fisik, benda yang benar-benar nyata. Sedangkan benda-benda atau peristiwa-peristiwa yang tidak ada hubungannya secara jelas dan konkret dengan realitas masih sulit untuk dipikirkan oleh anak ${ }^{142}$

Kemampuan-kemampuan kognitif akan semakin berkembang hingga anak memasuki tahap pemikiran operasional formal, yakni suatu tahap perkembangan kognitif yang dimulai pada usia kira-kira 11 atau 12 tahun dan terus berlanjut sampai remaja mencapai masa tenang atau dewasa. Secara umum karakteristik pemikiran remaja pada tahap operasional formal ini adalah diperolehnya kemampuan berpikir secara abstrak, menalar secara logis dan menarik kesimpulan dari informasi yang tersedia. Pada tahap ini, anak yang menginjak usia remaja sudah dapat berpikir secara abstrak dan hipotesis, sehingga dia mampu memikirkan sesuatu yang akan atau mungkin terjadi. Pemikirannya tidak lagi terbatas. Mereka juga sudah mampu berpikir secara sistematik, mampu berpikir dalam kerangka apa yang mungkin terjadi, bukan hanyaa apa yang terjadi. Mereka memikirkan semua kemungkinan secara sistematik untuk memecaahkan suatu permasalahan. ${ }^{143}$

Dengan demikian, seorang yang sudah masuk dalam tahap ini sudah bisa melakukan sebuah penalaran dalam evaluasi berbahasa dan memecahkan sebuah permasalahan yang terdapaat dalam butir-butir soal yang diberikan oleh pendidik.

\section{E. Perkembangan kognitif dari sisi bahasa (Pemerolehan bahasa)}

Bahasa tidak akan pernah lepas dari manusia, oleh karenanya bahasa selalu dipergunakan sebagai alat komunikasi seseorang kepada seseorang yang lain, dan dengan bahasa itulah mereka bisa saling mendapatkan berbagai macam pengalaman berharga dari yang lainnya. Dalam proses pendidikan, sebagian

${ }^{142}$ Desmita, Psikologi perkembangan anak,... 105-106
${ }^{143}$ Desmita, Psikologi perkembangan anak,... 107-108

Jurnal Ilmiah Al QALAM, Vol. 12, No. 1, Januari-Juni 2018 
Dony Ahmad Ramadhani: Evaluasi Bahasa Arab dalam Ranah Kemampuan Kognitif Peserta Didik

orang menyamaratakan sistem pembelajaran antara bahasa pertama dengan bahasa kedua, karena cara pemerolehannya sebenarnya adalah sama, yang berbeda hanyalah pada sisi tempat bahasa itu diperoleh. Jika bahasa pertama diperoleh saat masih kanak-kanak, maka bahasa kedua diperoleh pada saat anak tersebut baru/akan mempelajarinya sesuai dengan kemampuannya dan pada saat waktu yang tepat sesuai dengan kemampuan berfikirnya. Sebagian lagi menganjurkan agar bahasa pertama tidak disandingkan dengan bahasa kedua pada waktu yang sama, hal ini karena ditakutkan bahwa kedua bahasa tersebut tercampur aduk, dan sang anak tidak dapat membedakan mana bahasa pertama dan mana bahasa kedua. Oleh karena itu perlunya ada perbedaan waktu untuk mencapainya.

Adapun proses perkembangan anak dalam memperoleh bahasa, terbagi ke dalam empat tahapan ${ }^{144}$

1. Fase sebelum mengenal bahasa; fase ini biasanya ditandai dengan sebuah teriakan ataupun tangisan, karena sang anak belum sama sekali mengenal bahasa dan dia menjadikan tangisan dan teriakan sebagai bahasanya sendiri

2. Mengulang-ulang suara; fase ini bisa juga disebut dengan pengenalan bunyi bahasa dan huruf

3. Mengikuti; anak mengikuti apa yang di dengarnya, seperti halnya ketika seorang ibu ingin memberikan anaaknya makan, maka dia akan mengucapkan "mam" atau "mamam", yang kemudian sang anak akan berusaha untuk mengikutinya ketika di lain waktu ingin makan

4. Mempraktekkan; mengucapkan bahasa yang telah dia ketahui

Sedangkan menurut Watson menyimpulkan proses pemerolehan bahasa seorang anak sebagai berikut: ${ }^{145}$

144 Muhammad Ahmad As Sayyid, Al Lughah...Tadrisan Wa Iktisaaban (Riyadh: Al Mamlakah Al Arabiyyah As Su'udiyyah, 1988), h. 20

${ }^{145}$ Muhammad Ahmad As Sayyid, Al Lughah...Tadrisan Wa Iktisaaban,...h. $31-32$

Jurnal Ilmiah Al QALAM, Vol. 12, No. 1, Januari-Juni 2018 
Dony Ahmad Ramadhani: Evaluasi Bahasa Arab dalam Ranah Kemampuan Kognitif Peserta Didik

Fase pertama: berbicara sesuatu dengan berirama, maksud berirama di sini adalah, adanya pengenalan huruf dan cara pengucapannyaa sesuai dengan irama bahasa yang akan digunakan

Fase kedua : berkomunikasi dengan satu kata seperti "mama" dan "bapa", dalam tahapan ini, seorang anak tidak akan bisa secara instan membuat sebuah kalimat, namun dia hanya bisa menggunakan kata satu persatu

Fase ketiga : berkomunikasi dengan 4 atau 5 kalimat, dalam fase ketika seorang anak baru bisa menggunakan kalimat-kalimat yang bersambung dengan cara menirukan apa yang dia dengar

Fase keempat : bisa memberi nama 4 atau 5 benda yang dikenal. Adapun benda yang dimaksud adalah benda yang sering dia temui dan berada di sekelilingnya

Fase kelima : bisa menggunakan kata bermakna banyak (jama'), menggunakan kata sambung seperti "di, ke dan kata lainnya"

Fase keenam : dapat mengenali warna-warna, dan dia mampu menirukan apa yang diperbuat oleh hewan-hewan yang jinak seperti kucing dan anjing, menamai sesuatu yang terdapat dalam gambar, dan dapat mengulang-ulang 3 angka setelah mendengarnya.

Fase ketujuh : bisa menggunakan kalimat-kalimat secara jelas dengan mudah, mengetahui antonim kata, seperti besar kecil, kasar halus, berat ringan dan lainnya, dia juga mengetahui kapan berkata; silahkan, terima kasih

Fase-fase di atas menjelaskan bagaimana seorang anak mencapai atau memperoleh bahasa sampai bisa menggunakannya, dan itu semua bisa digunakan dalam proses evaluasi bahasa kedua sesuai dengan tingkat fase apa saja yang sudah dia lewati.

Dari fase-fase di atas, dapat disimpulkan bahwa rentetan pemerolehan bahasa yang akan disamakan dengan bahasa ke dua sebagai berikut; pengenalan huruf, komunikasi dengan satu kata, mengenal susunan kata, mengenal perubahan kata (Pemahaman), penggunaan kalimat secara utuh (Aplikasi). 
Dony Ahmad Ramadhani: Evaluasi Bahasa Arab dalam Ranah Kemampuan Kognitif Peserta Didik

Dalam pembelajaran bahasa, mengenal susunan kata terbagi menjadi dua bagian, yang pertama berfokus pada kalimat-kalimat yang sudah baku atau jadi dan kedua mempelajari uslub bahasa dari sisi Gramatikal. Namun gramatikal akan diajarkan secara utuh ketika kalimat-kalimat baku sudah diajarkan.

\section{F. Tipe-Tipe Hasil Belajar Kognitif Bahasa Arab}

Dari penjelasan sebelumnya, baik dari segi perkembangan psikologis maupun bahasa. Dapat disimpulkan, bahwa pembagian evaluasi bahasa berdasarkan tingkat kemampuannya dapat dibagi menjadi tiga tingkatan; Tingkat Pemula, Tingkat Menengah dan Tingkat lanjut.

Jika ingin diurutkan secara umum sesuai dengan perkembangan yang telah dijelaskan sebelumnya, maka evaluasi yang difokuskan sesuai dengan ranah kognitif peserta didik, dapat diklasifikasikan sebagai berikut; Pengetahuan huruf dan irama, pengetahuan hapalan, pemahaman, aplikasi, analisis. Adapun penjelasan ringkasnya sebagai berikut:

1. Pengetahuan tentang huruf dan irama

Tingkat ini hanya difokuskan kepada tes berupa pengenalan huruf dan irama seperti kata "علّم", terdidik dituntut untuk mengenali huruf tersebut, seperti tunjukkan kalimat yang di dalamnya terdapat Syiddah. Adapun yang dimaksud irama adalah lantunan-lantunan yang keluar dari penyebutan huruf.

Butir-butir soal seperti ini lebih banyak diberikan ketika peserta didik mempelajari bahasa kedua di Sekolah Dasar atau Madrasah Ibtidaiyyah. Karena memang pada masa awal-awal belajar, kemampuan mereka belum bisa difokuskan secara utuh ke dalam bahasa kedua.

2. Pengetahuan hapalan

Dalam hal ini terdidik hanya dituntut kembali mengulang kembali atau menghafal saja pelajaran yang sudah dipelajari 
Dony Ahmad Ramadhani: Evaluasi Bahasa Arab dalam Ranah Kemampuan Kognitif Peserta Didik

Fokus tes pada tahapan ini adalah penguatan bidang hapalan, dalam bahasa Arab biasanya hapalan berupa kosa-kata, baik dalam bentuk satu kalimat ataupun terdiri dari pada beberapa kalimat, tergantung pelajaran yang diikuti oleh peserta didik.

Tes dalam ranah penguatan hapalan ini pun beragam, berdasarkan dengan penjelasan pada fase-fase di bidang pemerolehan bahasan, maka penulis membagi tes penguatan hapalan bidang kosakata menjadi 3 bagian.

a. Kosakata per-kata; yakni tes kosakata hanya berupa 1 kata saja, seperti "بيت، كوب، مفتاح" dan lainnya

b. Kosakata dalam per-dua kata; yakni tes kosakata yang terdiri 2 kata, seperti "بيت مجمد"

c. Kosakata dalam bentuk kata sempurna yang terdiri dari dari 3 atau 4 kata, seperti "ذهبت إلى المدرسة"

Tes ini bisa diujikan kepada para pemula, karena memang tes dan pembelajaran yang paling utama bagi pembelajar bahasa adalah kosakata, tanpa kosakata akan terasa lebih sulit untuk memahami teks yang nantinya lebih panjang dan lebih sulit. Jika dalam tingkatan dasar, tes bisa dilakukan dimulai sekitar umur 10 tahun, karena sudah masuk masa oprasional formal sehingga lebih mudah untuk menerima bahasa kedua.

3. Pemahaman

Tingkat kognitif selanjutnya adalah pemahaman, pada tingkat ini, peserta didik sudah bisa memahami sebuah kejadian dan timbal balik dari sebuah kejadian, walaupun pemahaman ini sudah mulai berkembang pada masa SD, namun akan mulai berkembang secara efektif pada sekita umur 11 tahun. Jika dilihat dari fase pemerolehan bahasa, maka tingkat ini akan dimulai pada fase kelima. Pemahaman ini selalu berhubungan dengan memahami isi atau makna, baik berupa teks 
Dony Ahmad Ramadhani: Evaluasi Bahasa Arab dalam Ranah Kemampuan Kognitif Peserta Didik

ataupun kejadian-kejadian. Memahami sebuah teks/kejadian dari sisi arti katanya saja, atau bisa juga disebut dengan terjemah.

Dari segi karakteristik dalam penyusunan butir soal, sebenarnya relatif mudah dan sering digunakan dalam berbagai macam evaluasi bahasa yang bukan hanya terdapat pada bahasa Arab saja. Walaupun pembuatannya tidaklah semudah memahami karakteristiknya, karena butir-butir soal hendaknya diatur sedemikian rupa sesuai dengan kemampuan peserta didik, adapun karakteristik butir soal yang berfokus kepada pemahaman menentukan tema sebuah teks, baik teks yang diperdengarkan atau dibaca, menentukan sebuah topik pembicaraan, dan penerjemahan.

4. Aplikasi atau penerapan

Aplikasi adalah kemampuan peserta didik dalam menerapkan pengetahuan yang dia miliki seputar bahasa, baik dari sisi teori atau penggunaan bahasa secara utuh. Penekanan yang dilakukan pada tes ini adalah sebuah penerapan dari bahasa itu sendiri, yang artinya peserta didik dituntut untuk menggunakan bahasa yang telah dipelajarinya, baik dari sisi tulisan maupun lisan. Tes ini pun relatif berguna pada umur 11 tahun ke atas sebagai pelajaran bahasa kedua setelah bahasa ibu.

5. Analisis

Analisis ditujukan untuk mengetahui seberapa dalam pengetahuan terdidik terhadap bahasa yang sedang atau telah dipelajari. Peserta didik dituntut untuk menganalisis stuktur bahasa atau sebuah kejadian yang disajikan dalam sebuah teks bahasa Arab. Hal ini dimaksudkan karena adanya beberapa perbedaan struktur bahasa pertama sebagai bahasa ibu dan bahasa kedua. Adapun kemampuan analisis pada setiap tingkatan umur akan selalu berbeda, namun dengan adanya perbedaan tersebutlah, seorang pendidik dituntut agar kreatif dalam memberikan sebuah soal yang sesuai dengan tingkat kemampuan peserta didiknya. 
Dony Ahmad Ramadhani: Evaluasi Bahasa Arab dalam Ranah Kemampuan Kognitif Peserta Didik

\section{G. Contoh Butir Soal Berdasarkan Kemampuan Kognitif}

Berikut contoh salah satu butir soal berdasarkan kemampuan kognitif:

1. Pengetahuan tentang huruf dan irama

Kosakata berikut yang bunyi awalnya berupa " $ع "$ adalah:
a. حليم
b. أليم
c.
عليم 146

2. Pengetahuan hapalan

Arti kata "الجامعة" adalah
a. Mesjid
b. Perguruan Tinggi
c. Lab. Bahasa
d. Yayasan

3. Pemahaman

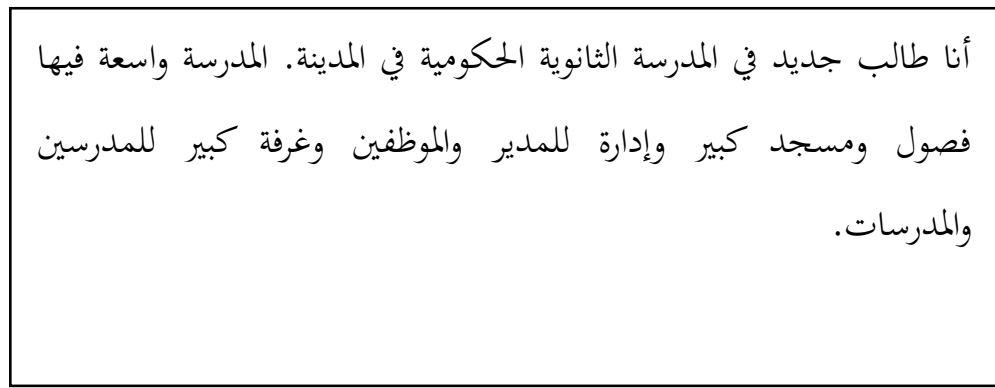

$$
\text { مالموضوع المناسب للقراءة السابقة؟ }
$$

146 M. Ainin DKK, Evaluasi Dalam Pembelajaran Bahasa Arab (Malang: Misykat, 2006), hal. 72.

Jurnal Ilmiah Al QALAM, Vol. 12, No. 1, Januari-Juni 2018 
Dony Ahmad Ramadhani: Evaluasi Bahasa Arab dalam Ranah Kemampuan Kognitif Peserta Didik
a. أحوال المدرسة
b. عنوان المدرسة
c. طالب جديد
d. مدير المدرسة
e. 147 ميدان المدرسة

\section{Aplikasi}

$$
\text { التلميذ - من - حرج - الفصل }
$$

$$
\text { أصح الترتيب للكلمات السابقة هو... }
$$
a. التميذ من الفصل خرج
b. من الفصل خرج التلميذ
c. التلميذ خرج من الفصل
d. خرج من الفصل التلميذ

\section{Analisis}

$$
\begin{aligned}
& \text { زار جميل وجلال معرض الهوايات في جدة. في معرض الهوايات جناح جمع } \\
& \text { الطوابع، وجناح الخط العربي، وجناح الصحافة، وجناح الرياضة }
\end{aligned}
$$

${ }^{147}$ Soal UAMBN Bahasa Arab tahun 2014

${ }^{148}$ Al Arabiyyah Lin Nasyiin (Al Mamlakah Al Arabiyyah As Suudiyyah, Jilid 1), hal. 9

Jurnal Ilmiah Al QALAM, Vol. 12, No. 1, Januari-Juni 2018 
Dony Ahmad Ramadhani: Evaluasi Bahasa Arab dalam Ranah Kemampuan Kognitif Peserta Didik

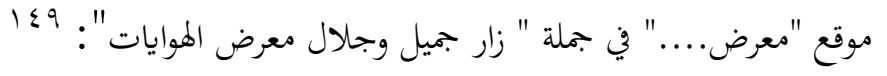
a. مغعول مطلق
b. مفعول به
c. مفعول des
d. مفعول لأجله

\section{H. Penutup}

Evaluasi dalam ranah kognitif sebenarnya difokuskan dalam hal penempatan apakah peserta didik sudah siap menerima tes evaluasi sesuai dengan perkembangan yang dimilikinya atau tidak, sehingga tidak akan mempersulit peserta dalam menjawab butir-butir soal yang telah diberikan. Oleh karena itu, diharapkan kepada para pendidik agar lebih memperhatikan evaluasi dalam ranah ini, sehingga evaluasi yang dilaksanakan pun terasa mudah namun tetap memberikan manfaat besar untuk para peserta yang telah mengikuti proses pembelajaran

${ }^{149}$ M. Ainin DKK, Evaluasi Dalam Pembelajaran Bahasa Arab,...hal 75

Jurnal Ilmiah Al QALAM, Vol. 12, No. 1, Januari-Juni 2018 
Dony Ahmad Ramadhani: Evaluasi Bahasa Arab dalam Ranah Kemampuan Kognitif Peserta Didik

\section{Daftar Pustaka}

Ainin, M. DKK, Evaluasi Dalam Pembelajaran Bahasa Arab (Malang: Misykat, 2006)

As Sayyid, Muhammad Ahmad, Al Lughah...Tadrisan Wa Iktisaaban (Riyadh:

Al Mamlakah Al Arabiyyah As Su’udiyyah, 1988)

Al Arabiyyah Lin Nasyiin (Al Mamlakah Al Arabiyyah As Suudiyyah, Jilid 1)

Desmita, Psikologi perkembangan anak (Bandung: PT Remaja Rosdakarya, 2012), Cet ke 4

Ibda, Fatimah, Perkembangan Kognitif: Teori Jean Piaget (Jurnal Intelektualita-Vol. 3.No. 1, Januari-Juni 2015)

\section{KBBI}

Purwanto, M. Ngalim, Prinsip-Prinsip dan Teknik Evaluasi Pengajaran (Bandung : PT. Remaja Roosdakarya, 2008)

Soal UAMBN Bahasa Arab tahun 2014

Jurnal Ilmiah Al QALAM, Vol. 12, No. 1, Januari-Juni 2018 